\title{
Free Online Services: Enabling, Disenfranchising, Disempowering
}

\author{
Luciano Floridi $^{1}$
}

Published online: 17 May 2015

(C) Springer Science+Business Media Dordrecht 2015

It is Christmas and your aunt has knitted a scarf for you. It is beautiful, useful, and you needed it. In fact, you love it. You feel that she cares about you and understands your wishes. You are most grateful for such a thoughtful gift. It seems that everybody is happy. How can there be anything wrong with such a win-win scenario? This is the same rhetorical question asked by many defenders of free online services. The answer is supposed to be stronger than a mere "nothing". It is supposed to be a much more positive "there is everything right with this!". Indeed, the new rhetorical question becomes "what's wrong with you, killjoy?". For the digital gifts from Baidu, Expedia, Facebook, Flickr (Yahoo!), Google, Instagram (Facebook), LinkedIn, Microsoft, Tencent, TripAdvisor, Tumblr (Yahoo!), Twitter, Yahoo!, YouTube (Google), WhatsApp (Facebook) and all the other thousands of digital aunts, we seem to have online ensure that we, the giftees, are part of the information society, that we live on the good side of the digital divide and that we enjoy all the amazing fruits of our technological developments. And all these, free of charge. They make every day feel like Christmas.

End of story? Not quite. Think more carefully and critically and you will realise that "timeo Danaos et dona ferentes" may still apply. The Latin phrase means "I fear the Greeks even when they bear gifts". In the Aeneid, Virgil makes the Trojan priest Laocoön utter this now proverbial line, in his attempt to warn the Trojans not to accept the famous wooden horse left by the Greeks as an apparent gift. We know how it ends. And yet, we seem to be falling into the same trap. Let me explain.

The digital gifts we are receiving have three features that should make us think twice before we accept them gratefully. I already mentioned the first: they are indeed enabling us in countless ways and immensely more than a simple scarf. It is hard to imagine what life would be like without them for anyone so used to rely on them daily. This is why they work; when they do, they become an essential part of our onlife

Luciano Floridi

luciano.floridi@oii.ox.ac.uk

1 Oxford Internet Institute, University of Oxford, 1 St Giles, Oxford OX1 3JS, UK 
experience. However, as gifts, they are also disenfranchising in a very important sense. Digital services as temporary gifts need neither justification nor legitimization, including the oldest form of legitimization, namely, ownership, now replaced by authorised use. When using a digital gift, Alice is neither a customer nor a citizen; she is merely a user. She can either take it or leave it, but she has no right to complain, for she did not pay for the service and neither did she vote for it. There is no contract, whether legal or social, only disclaimers and terms of service by which Alice must agree to abide in order to use the service. If she does not like the scarf she can always stop using it; it would be preposterous if she were to engage in any legal action against her aunt for the poor quality of the wool, the awkward length, the hideous colours or the fact that the colours are those of a football club, which will identify Alice as a supporter of a specific team she does not care about. Her aunt would be sincerely astonished and appalled by her ingratitude. It is a gift and gifts, as opposed to purchased or tax-paid goods or services, have the special property of removing the right to complain or choosing. Likewise, if digital gifts are useless or unwelcome, the market will take care of them; perhaps, better ones will follow. If they are useful, they may become essential and generate both dependency and grateful loyalty, although the lack of any possible reciprocity may transform gratitude in resentment for an unequal dependency, and thus turn the gifts into poisonous ones, when giftees quickly turn against the gifters (consider how quickly Google moved from being a hero to being a foe). All this also explains why our digital aunts are determined to create monopolies. The search market in Europe, entirely dominated by Google, is typical. When it is freezing and that is the only scarf Alice can wear, it is hard for her not to be happy and grateful for it.

So, free online services as gifts both enable and disenfranchise their users. They also disempower those who produce and sell alternatives for a price, that is, they put the competition out of business. This is the third important feature that I wish to highlight. Alice's aunt and her knitting skills undermine the shop that would have sold the scarf that Alice needed and wanted. By presenting Alice with a free scarf, her aunt is disempowering a previous business. And with that shift in "business", there follows a shift in power. The aunt is now the free source to whom Alice turns, the one on whom she depends, perhaps for a new scarf and a matching hat next Christmas. Giving away a service or good for free means disempowering any other agent whose business is based on selling that service or good. This explains why our digital aunts tend to make any kind of information dirt-cheap. The production and control of information was the old business model of the mass-media society and its source of influential power. In mature information societies, information is commoditised into undifferentiated marketable items (sellable things so generic that customers perceive little or no value difference between brands or versions), especially through increased competition. Such a commoditisation ends up decreasing prices until it becomes economically more profitable to produce and give information away for free in exchange of personal data, by relying on an advertising-based business model. This commodification assigns economic value to something not previously considered in economic terms - such as data about individuals' purchasing power, patterns and preferences - making them subject to supply-demand and price-value dynamics. An important side effect is that this creates a reinforcing cycle in which the escalating need to differentiate products further fuels the same mechanism that tends to commoditise them. The more the digital business cannibalises the analogue business, the more the analogue business needs 
the digital to ensure that it is not entirely cannibilised, increasing the resources spent on advertising, that is, on signalling campaigns that seek to resist commoditisation. In more colourful terms, the analogue is like a mediaeval knight or king who is constantly captured by a digital foe to whom he has to pay a ransom to be freed until he is captured again. The digital cannot believe his luck. In this process, digital companies can further fuel the disenfranchising strategy towards their users - more free goodies as giftswhile further disempowering those who held power in mass-media societies based on the production of information rather than on its mediation, management, search, repackaging, free sharing and so forth. Apple disempowers the music industry, Amazon the printing industry, Google the news industry, TripAdvisor and Expedia the travel industry and so on. As you can see, any Manichean interpretation of good vs. bad forces is utterly naïve. The old analogue barons are being replaced by the new digital ones. Good forces, such as newspapers, public libraries and the journalistic profession are collateral damages. They emerged as a consequence of the printing revolution, as a way of coping with the risk of monopoly on information production. Today, information is commoditised, there is no monopoly-consider the blogosphere, citizen journalism or Google books - and so they are becoming solutions in search of a problem.

Not every digital aunt replaces a previous business and corresponding power from the old mass-media society. Some cases are borderline, like Amazon's policy with its sale of under-priced Kindle readers. The more they are subsidised the closer they look like gifts for their users. Some other cases, like Facebook, seem to have identified new sources of commodification, essentially gossip, socialising and communication online. Others still are just entering the market of free gifts in exchange of personal data; think of the services associated to Apple's watch. In all cases, when the digital aunts clash with previous business models, they have the powerful advantage of free and enabling gifts on their side. Resistance is futile.

In some societies, gift economies are complex and finely tuned modes of exchange governed by social norms and customs in which valuables are not sold for money or some other commodity, but are presented without an explicit agreement for immediate or future rewards. Through the masterful exploitation of two-sided markets - in which two distinct user groups, which provide each other with network benefits, are enabled to interact by a platform - Silicon Valley has hacked (repurposed) the gift economy as a competing strategy in a very smart way. I just highlighted three main features of this new "digital gift economy". The whole mechanism is based on two variables. One is the absence of real, local competition: there is only one Amazon, one eBay, one Facebook, one Google and so forth. By their nature, two-sided markets tend to be dominated by one platform. The other is the availability of an immense, renewable resource, namely, the amount of money spent worldwide on advertisement every year. According to a recent report by eMarketer, "paid media ad spending worldwide will rise $5.9 \%$ to reach $\$ 577.79$ billion in 2015 . Digital ad spending will make up nearly $30 \%$ of the total, while mobile ad expenditures - which are driving growth — will account for $11.9 \% " .1$ According to data provided by the International Monetary Fund, ${ }^{2}$

\footnotetext{
${ }^{1}$ See http://www.emarketer.com/articles/results.aspx?q=global

${ }^{2}$ World Economic Outlook Database, April 2015, http://www.imf.org/external/pubs/ft/weo/2015/01/weodata/ index.aspx
} 
if this were the nominal GDP of a country, in 2014, advertisement would have ranked as number 21st in the world, ahead of Sweden ( $\$ 570.137$ billion). Ca. $30 \%$ of it is the ransom that the analogue pays to the digital. Both lack of competition and increasing advertising spending are largely self-regulated. The market, whether analogue or digital, takes care of them. This is also part of the disenfranchising nature of free online services: controllers control themselves in a close circuit of interactions to which all the Alices in the world are invited as mere users, who can no longer afford not to accept the offered gifts and be left out of the infosphere (Floridi 2003, 2013).

The cost of this macroscopic mechanism is twofold. On the one hand, there is an ever increasing pressure to acquire and process more and more personal data, which are the only thing that the online industry competes to sell to those who have to advertise their goods and services. The better the almost $\$ 600$ billion ads available every year are allocated the more privacy is being eroded (Floridi 2014). On the other hand, there is an increasing escalation in advertising budgets. This leads to an inefficient and skewed allocation of resources, with few winners taking all. In short, the outcome is less privacy and more inequality, two of the most serious problems in mature information societies, which now emerge as being linked like two distant branches of the same tree.

There is no simple solution, but socio-political institutions could do much to improve the situation, by promoting more competition, better taxation, and by regulating more strictly the advertising industry, perhaps by following some of the lessons learnt from the limits imposed on the tobacco industry and addressing the problem of how much money can be wasted in this new arms race (imagine for a moment what life would be like if paid advertisements were illegal). As long as it is rational to offer gifts in return for increasingly less privacy and higher advertising revenues do not expect much improvement in the future.

\section{References}

Floridi, L. (2003). Informational realism. In W. John \& A.-S. Yeslam (Eds.), Selected papers from conference on computers and philosophy (Vol. 37). Darlinghurst: Australian Computer Society.

Floridi, L. (2013). The ethics of information. Oxford: Oxford University Press.

Floridi, L. (2014). The fourth revolution-how the infosphere is reshaping human reality. Oxford: Oxford University Press. 